\title{
FUNCTIONAL AND SEMANTIC FEATURES OF THE ENGLISH COMPOSED ADJECTIVES (BASED ON THE ENGLISH FICTION DISCOURSE)
}

Shumenko O. A., PhD in Philology, Associate professor, https://orcid.org/0000-0002-7846-1937

E-mail: shuma-81@ukr.net

Inshina $N$., student,

Kashenko P., student,

Kostriukova $V$., student,

Sumy State University,

2 Rimsky-Korsakov St., Sumy, 40007, Ukraine

This article is devoted for comprehensive research of semantic features of composed adjectives on materials of artistic English language discourse. The topicality of this text is based of modern linguistic tendency to in-depth study functional parameters of composed adjectives like an important elements of language picture of the world. The main goal of this article is researching of semantic behavior of composed adjectives depending on their components. On the basis of studying the structuring of complex adjectives, lexical-semantic groups are distinguished the sum of the values of the two components affects their significance. For reaching our goal we had detailing analyzed texts from English literature which became a source of information about functional and semantic properties of adjectives. Major categories of composed adjectives are highlighted: Noun + Adjective, Adjective +Adjective, Numeral + Past Participle and Adjective + Past Participlel Adjective + Present Participle. The main content of the study is analysis of the last group of composed adjectives which consist of two groups: Adjective + Past Participle and Adjective + Present Participle. This type is characterized the adjective most fully, where second component, a participle is core of the word meaning which determine semantic of composed adjective. Another types of composed adjectives give a possibility to understand that they do not change their structure when translating and reveal the center of meaning in adjectives of this structure is impossible, because these basis are equal and have predicative connection.

Key words: semantic charge, nuclear basis, composed adjectives, model of formation. https://doi.org/10.21272/Ftrk.2018.10(3)-13

The article is devoted to the study of composed adjectives in English as important components of linguistic global picture. We have researched the development of English composed adjectives, their semantic features and functional characteristics. The article has focused on the peculiarities of the semantic charge of the English composed adjectives, which facilitate their connection with the nouns they characterize.

In modern linguistics there was a tendency to study the systemic-functional features of linguistic units [1]. The appeal to this topic is conditioned by the need for the comprehensive study of the ways and means to add the lexical composition of English language. The study of complex adjectives is relevant given the comprehension of the partspeaking nature of nominative units, the nature of the secondary design of new units and their semantic markers [7, p. 145]. Recently, communicative linguistics is rapidly developing and demonstrates the benefits of researching the semantics of the word through its use, since the use of words in different combinations leads to the transformation of their semantics and the appearance of new meanings. It is in the context of the most clearly revealing potential meanings that determine the semantic structure of the word.

The vocabulary of English is enriched by lexical and semantic derivation [11, p. 8]. The vocabulary of any language is known to be in a state of continuous change. This mobility and its variability is due to the fact that the language, and first of all, its vocabulary, directly related to the production and social activities of people. To fulfill its most important function - the means of communication - the vocabulary of the language must quickly

(C) Shumenko O. A., Inshina N., Kashenko P., Kostriukova V., 2018 
respond to changes in all spheres of life and activities of people. Thus, quantitative growth and qualitative changes in the vocabulary of the language are ultimately connected with the history of the people - the creator and the bearer of this language [10, c. 26].

The creation studies derivation, that is, the formation of new words with a certain lexical and semantic meaning through productive ways of creation: affixation (preffixation and suffixation), conversion, reduction, word-building. The term «derivate» is used to refer to the morphological, syntactic, and semantic word-formation using existing in the language of «building» material and models [6]. Productive way of word-formation in both Ukrainian and English languages is assembling. «Formation is a way of creating complex words by combining two or more bases or whole words or their abbreviations» [6]. As a result of composition, compound words are formed. The types of compilation include basic compilation, word-formation and abbreviation [3].

The urgency of the topic is determined by the tendency of modern linguistics to indepth systematic study of various types of word-building, systemic-functional options of linguistic units, including journalistic in the interaction of their semantic characteristics, little research of composed adjectives, tendencies of transformations, and the need to clarify the features of the semantics of adjectives.

The object of the study is English composed adjectives; the subject of the study is their functional and semantic characteristics.

The purpose of the work is to describe the process of creating composed adjectives in the English language, to study their semantic behavior, as well as to identify the surface and depth structures of composed adjectives. In accordance with this goal, the following main tasks are fulfilled:

- to distinguish and characterize the lexical-semantic group of composed adjectives of English language;

- to analyze the syntagmatic properties of the studied adjectives with subclasses of nouns in artistic English-language works;

- compare the features of the use of adjectives in the author's style;

- establish the relation between the number of values of adjectives in Englishlanguage works and the frequency of their use in the text;

- to reveal the functional-semantic character of secondary instances of the adjectives.

Research methods. Execution of tasks envisaged in the work necessitated the complex application of various methods. The method of linguistic description is used to analyze and generalize the data on the structural and functional features of English adjectives. Component and contextual analysis methods are used to inventory the lexical-semantic group and clarify the semantic structure of the studied adjectives. Statistical methods made it possible to obtain data on semantic relations between components of composed adjectives.

The material of the study served as text examples from the works of English literature of the twenty-first century. The total volume of the studied units - about 2000 word-wise, which became the source of information about the functional and semantic properties of the adjectives of English language.

Due to a number of objective reasons, the adjective (as part of the language) is one of the least studied and not easy to study categories of lexical units. The first reason is that many languages do not consider the adjective as an independent part of the language, therefore, it can act as a subclass of the noun or as a subclass of the verb. That is why the adjective can not be regarded as a unique class, in contrast to the noun and the verb, because in many languages of the world the adjective does not distinguish a separate part of the language that has its own morphological or syntactic features, they are part of the derivative words from the verb and different names [10].

However, the majority of researchers of parts of the language recognize the affiliation of the adjective vocabulary to nominative units, which in the language are represented by objective and indicative digits of words. The first group is filled with nouns, in the second adjective and verb. The first group includes nouns, and the second one is verbs and 
adjectives. Consequently, the adjective is a part of the language, indicating the sign of the subject, for example: en. cultured - ukr. інтелігентний, en. beautiful - ukr. красивий, en. white - ukr. білий, en. thirsty - ukr. спраглий, en. smart - ukr. розумний. Adjectives are used to describe objects, people, etc. In English, adjectives are popular, which are combined with nouns and pronouns [4, p.147]. There are many different adjectives classifications, but the traditional division divides them into two groups: Qualitative Adjectives and Relative Adjectives. Qualitative adjectives characterize things, people, and perception by sensory organs, their size, form, color, etc. Qualitative adjectives denote the "quality" of the subject directly, for example: en. long tail - ukr. довгий хвіст, en. dark hair - ukr. темне волосся, en. bluе еуеs - ukr. блакитні очі. They also have degrees of comparison, from which you can create the abstract term: warm-warmth, dark-darkness.

Different types of properties of subject and event are expressed by the relative adjectives [12], they almost always relate to the names of persons, objects, events, actions. Relative adjectives always describe the quality of the subject in terms of their relation to the material, place, time, and connection, but they do not have degrees of comparison: en. wooden door - ukr. дерев'яні двері, en. Swedish language - ukr. иведська мова, еn. american girl - ukr. американська дівчина. Very often, as the relative adjectives in English, are the nouns (determinants) that lie before the noun to which they belong. For example: en. homeless canteen - ukr. їальня для безпритульних, en. baseball match ukr. бейсбольний матч, en. sumтеr sports - ukr. літні види спорту. Unique adjectives in English are absent, they are replaced by nouns in the possessive case, for example: en. Jason's cat - ukr. кіт Джейсона, en. father's birthday - ukr. день народження батька, en. Colin's car - ukr. автомобіль Коліна [14].

Composed adjectives (CA) are an integral part of any language, that is, they act as determinants that characterize certain properties, certain attributes. For the most part, CA are used to express their emotions, feelings, in order to give a vivid characterization of events and processes. Most of the composed adjectives formed in the process of development of the surrounding reality. The process of formation of a joint venture consists of two stages. The first stage is the combination of sounds in a word that has its meaning, and the second stage is the combination of two seams with their own values, one that acquires an entirely new meaning, does not look like the previous, which totally differs from the value any of the component words. The value of CA is influenced by two factors: the contextual environment and the syntactic value of two or more components, that is, the common sense of the CA is determined by a set of values of the two components [5, 8].

The study of the surface and depth structures of the CA is relevant, given the need to study the collision, as well as the exploratory effectiveness of the human factor. It is the cognitive properties that influence the adequate understanding of the translation texts. Composed adjectives, as language constructs, have their structure, formal and semantic significance, for example: en. red-neck - ukr. селянин, when translating each component separately, we receive a translation червона шия / з червоною шиєю, but with the use of cognitive abilities, we can draw certain parallels, that is, people who work on the earth under the blazing sun for a long time have a tendency to reddening the skin. So, we applied the correlation of real/ unreal events, historical facts, legends, which led to an adequate translation. The semantic value of the CA is determined by the components from which the complex adjective forms. Since the CA belongs to free expressions, there are several types of CA that have their own version with a different semantic formula. Semantics is a rather complex system characterized by heterogeneity of units, a multiplicity of its structure, and most importantly - openness for the constant replenishment of new words and values [9].

Consider en. snow-white - ukr. білосніжний means «as white as snow» (білий як сніг), that is, the underlined content link in this case is a pronounced comparison. By the syntactic structure, this type of CA - Noun + Adjective. The fact is that in this type of CA there is no leading word that changes the semantic charge of the entire adjective. Visually dividing this adjective on the left and right sides, we see that the noun snow can be replaced by another noun, but such that it would be appropriate to match the semantic meaning, for example, 
sheet, we obtain a CA: en. heet - white - ukr. білий means «as white as sheet» (білий, як простирадло). We also demonstrate with the right part, replacing the adjective white on bright, taking into account the logical connection in this CA, we get snow-bright -ukr. яскраво-білий means «as snow as bright» (як сніг яскравий). Examples that are completely related:

- with colours: en. blood-red-ukr. багряний; en. head-red-ukr. pyduй; en. sky-blue - ukr. блакитний; en. pitch-black - ukr. смоляно-чорний;

- with size and weight: en. kneе-deеp - ukr. глибоко занурений, en. breast-high ukr. занурений по груди, en. nation-wide - ukr. всенародний, en. life-long - ukr. довічний, en. world-wide - ukr. всесвітньо відомий, en. - They talk about how the sun turned bloodred before it set, ukr. - Про те, як сонце, занурюючись у хвилі, стало червоним як кров (Kate Thompson. Secrets of the Sewing Bee, p. 45); en. - And her heart, I suspect, as soot - black, ukr. - I ï̈ серце, підозрюю, так само чорне, як сажа (Harry Keeble with Kris Hollington, Hurting too much, p. 309); en. - Three-piece rock outfit with a smoking hot head-red on drums, ukr. - Колектив з трьох чоловік, з гарячою руденькою на ударних (Alice Peterson, A song for tomorrow, p. 22).

By semantics, adjectives are very heterogeneous, their classifications are diverse and rely on both the value of the adjectives themselves and on the function of cognition. Adjectives are considered «classical» predicates, because they do not include any other properties, except for predicative ones. Such as the properties of things, physical qualities of humans and animals, internal and psychological properties, persistent qualities and temporal $[3,11]$.

Going to the second type of CA, consisting of two adjective bases, where the first one expresses the measure or feature of the second: en. red-hot - ukr. червоно-гарячий, полум'янии - Adjective +Adjective. Consider the adjective listed separately in parts, en. red - ukr. червоний, багряний, when translated, we get a meaning in the dictionary, which is quite capable of characterizing any phenomenon on its own. According to the second part en. hot - ukr. полум'яний, найяскравіший, the adjective can also freely act as a full member of the sentence. That is, in the adjectives of this type it is impossible to find the main part, since the two adjective bases are equal. Moreover, the given CA consists of two free parts, which can stand separately in the text and carry a certain semantic value. This type of CA is quite acceptable for a technical and scientific vocabulary: en. white-hot - ukr. розпечений, пекучий; en. bitter-sweet - ukr. гіркувато-солодкий; en. reddish-brown ukr. темно-каштановий, бурий; en. social-есопотіс - ukr. соціально-побутовий; en. A brown suit, brown shoes, a white shirt a grayish tie with reddish-brown, or brownishred, dots in it, ukr. - Коричневий костюм, коричневі черевики, біла сорочка сіруватий краватку з червоно-коричневими ияточками (Harry Keeble with Kris Hollington, Hurting too much, p. 219); en. - Improving social-economic situation of women from rural areas is a government concern, ukr. - Одним із завдань уряду є поліпшення соиіальноекономічного становища жінок в сільських районах (Alice Peterson, A song for tomorrow, p. 64); en. - Just a blinding white-hot furnace, ukr. - Просто cлinyчa розпечена піч (Kate Thompson. Secrets of the Sewing Bee, p. 129).

Since the adjective refers to the lexical-semantic class of predicate words [12], denoting non-procedural features (properties) of an object, then the following type of formation of the CA can also be distinguished adjectives like en. man-made - ukr. створений руками людини, which containing the noun-basis for the determinant and the verb form II. Semantic connections underlined in similar examples of adjectives are interesting in their semantic diversity: en. man-made «made by man» - ukr. створений руками людини (виражається через прикметник дія і виконавеиь діi); en. home-made «made at home» - ukr. саморобний (виражається ознака місия виконаної діï); en. safety-tested "tested for safety» - ukr. безпечний (виражається мета); en. - The weapons of most concern are, among others, handguns, assault rifles and home-made weapons, ukr. - Найбільше занепокоєння викликають, зокрема, такі види зброї, як пістолети, автомати $i$ саморобну зброю (Kate Thompson. Secrets of the Sewing Bee, p. 417); en. - No man- 
made drug could do that, ukr. - Жоден наркотик, створений людиною, на таке нездатний (Harry Keeble with Kris Hollington, Hurting too much, p. 148); en. - All firearms and military small arms should be safety-tested, ukr. - Вся вогнепальна $i$ військово-стрілецька зброя повинна бути безпечною (Alice Peterson, A song for tomorrow, p. 72).

English language adjectives are not only attributive functions, but also implement cognitive, stylistic, communicative and other functions. The cognitive function indicates the processes of the formation and functioning of adjective constructions, the basic milestones of the knowledge of complex adjectives in different types of discourses. Proceeding from this, the following type of CA is formed which is formed on the basis of free and stable phrases, which, being the equivalent of words, have the same semantics and go to a uniform form [11, p. 47]. Numeral + Past Participle: en. two-faced - ukr. лукавий, неправдивий; en. three-legged - ukr. триногий. In this case, the semantic charge of adjectives is semantically carried by adjectively-numerical composites, in which the complete basics of words, which relate to combinations, are constructed according to the types of subcontracting, are constructive. Such a composite has at least two components, the last of which is a noun or an adjectival basis, and the first one can be represented: a quantitative numerator or a numerical combination. It is noteworthy that the first adjective - two-faced formed on the basis of a stable phrase, which has a figurative meaning in a sense, and replacing the number two with the numerator three, we obtain a literal interpretation in which the actual content of the legal norm corresponds to the literal text en. three-facedukr. трьохликий, з фізичними вадами; en. - She's nothing but a manipulative, calculating, two-faced, ukr. - A вона була тільки маніпулюючою, розважливою, лукавою... (Harry Keeble with Kris Hollington, Hurting too much, p. 321); en. - It's like when we fed that three-legged dog with the filmy eye, and it kept coming around, ukr. Прямо як тоді, коли ми погодували триногу собаку з раненим оком, і потім вона весь час поверталася (Kate Thompson. Secrets of the Sewing Bee, p.367); en. - The Centre consists of two two-storeyed buildings, ukr. - Центр складається з двох двоповерхових будівель (Alice Peterson, A song for tomorrow, p. 347).

Taking into account the CA of this type, which in turn is divided into two subtypes, one can distinguish that most of the composed adjectives that are formed under such an Adjective + Past Participle scheme indicate that the first component is the core of the entire adjective. This can be considered on an example en. sour-faced - ukr. засмучений, the left part gives the character to every adjective and is a determinant. Replacing only the left part of this adjective, we change the basis, the semantic value of the entire adjective, for example en. gorgeous-faced - ukr. прегарний, розкішний. In addition, we can not consider this type of CA in separate parts, because the right faced part can not exist independently in the sentence. The same is true of adjectives of the scheme Adjective + Present Participle, en. peace-loving - ukr. миролюбний consists of a noun-base and a participle basis. Replacing the basis of peace on the noun is the opposite of the meaning of war, we get en. war-loving - ukr. військовий; бойовий; смертоносний [15]. It is noteworthy that when translating from the original language into the language of translation, a portable value is used, that is, a secondary value that arose on the basis of two components of the CA. Other examples of the same type: en. grubby-faced - ukr. неохайний; en. sassy-looking - ukr. нахабний, жвавий; en. far-teaching - ukr. віддалений, той, якого навчають на великій відстані, дистаниійно. Помітно, що основи -faced, -looking, -teaching не існують як окремі прикметники і не можуть виконувати в реченні роль прикметника: en. - Just think of me as your new sassy-looking assistant, ukr. - Просто вважай, щуо я твій новий зухвалий помічник (Alice Peterson, A song for tomorrow, p. 181); en. - You won't be so sour-faced when you have gold in your purse, a flagon of wine in one hand, and a beautiful woman in the other, ukr. - Ти не будеш настільки засмучений, коли буде золото в гаманиі, кружка вина в одній руиі і прекрасна жінка в інший (Harry Keeble with Kris Hollington, Hurting too much, p. 122); en. - We've found evidence that this woman might be war-loving criminal Death Walker, ukr. - У нас є підозра, шчо ия жінка - військовий злочинець, щчо несе смерть (Alice Peterson, A song for tomorrow, p. 86); en. - I'm sorry 
I've been so short-tempered lately, ukr. - Вибач, щзо був таким нестриманим (Kate Thompson. Secrets of the Sewing Bee, p. 297).

The semantic junction of CA, their metaphorical expansion, paraphrases, all this is an indicator of the ambiguity of the adjective, as part of the language, and this is precisely what determines its extensive study, both individually and in different environments. For a detailed study of the CA, we analyzed the structure of about 2000 selected units and the result was presented in the form of a table showing the models of some composed adjectives.

List 1

\begin{tabular}{|c|c|}
\hline Model & Example \\
\hline \multirow{3}{*}{$\begin{array}{l}\text { Adjective }+ \text { Present } \\
\text { Participle/Past } \\
\text { Participle } \\
\quad \text { (Sour-faced, } \\
\text { grubby-faced, } \\
\text { white-tiled) }\end{array}$} & $\begin{array}{l}\text { en. Hе made a sour face, } \\
\text { ukr. Він зробив кисле обличчя / Він скривився. }\end{array}$ \\
\hline & $\begin{array}{l}\text { en. Child was looking so grubby-faced, } \\
\text { ukr. Дитина виглядала досить неохайно. }\end{array}$ \\
\hline & $\begin{array}{l}\text { en. She was white-tiled with her parents, } \\
\text { ukr. Вона була відверта зі своїми батьками. }\end{array}$ \\
\hline \multirow{3}{*}{$\begin{array}{l}\text { Adjective }+ \text { Noun } \\
\text { (Short-staffed, } \\
\text { short-term, } \\
\text { weak-kneed) }\end{array}$} & $\begin{array}{l}\text { en. I seem to be - short-staffed at the moment, } \\
\text { ukr. Для цьього я не ... укомплектована на даний момент. }\end{array}$ \\
\hline & $\begin{array}{l}\text { en. Responses are typically short-term and «non-sustainable», } \\
\text { ukr. Відповідні заходи зазвичай носять короткостроковий } i \\
\text { «нестійкий» характер. }\end{array}$ \\
\hline & $\begin{array}{l}\text { en. The role of the dissenter is not for the weak-kneed, } \\
\text { ukr. Роль дисидента - не для слабовільних. }\end{array}$ \\
\hline \multirow{3}{*}{$\begin{array}{l}\text { Noun }+ \\
\text { PastParticiple } \\
\text { (Muddle-headed, } \\
\text { hand-woved, } \\
\text { hand- writer) }\end{array}$} & $\begin{array}{l}\text { en. Sarah, where's your muddle-headed husband? } \\
\text { ukr. Сара, де твій тупоголовий чоловік? }\end{array}$ \\
\hline & $\begin{array}{l}\text { en. The tablecloth was edged with a hand-woven pattern, } \\
\text { ukr. По краю скатертина була прикрашена витканим } \\
\text { вручну візерунком. }\end{array}$ \\
\hline & $\begin{array}{l}\text { en. The reis also a hand-written text by the author himself, to } \\
\text { the effect that he had no demands whatsoever, } \\
\text { ukr. Iснує також рукописний текст, в якому автор } \\
\text { підтверджує, що у нього немає ніяких претензій. }\end{array}$ \\
\hline \multirow{3}{*}{$\begin{array}{l}\text { Adjective + Present } \\
\text { Participle } \\
\text { (Good-looking, } \\
\text { smooth-talking, } \\
\text { fast-talking) }\end{array}$} & $\begin{array}{l}\text { en. Right? But, you know, he's reasonably good-looking, but..., } \\
\text { ukr. Вірно? Але, ви знаєте, він безумовно добре виглядає, } \\
\text { але... }\end{array}$ \\
\hline & $\begin{array}{l}\text { en. Our smooth-talking friend from the ice rink, } \\
\text { ukr. Hаш красномовний друг з катка. }\end{array}$ \\
\hline & $\begin{array}{l}\text { en. You're just a fast-talking car salesman that hides behind the } \\
\text { line, «I do good», } \\
\text { ukr. Ти просто балакучий продавець машин, що ховається } \\
\text { за фразою «Я творю добро». }\end{array}$ \\
\hline \multirow{3}{*}{$\begin{array}{c}\text { Numeral + } \\
\text { PastParticiple } \\
\text { (One-eyed, } \\
\text { one-armed, } \\
\text { two-toned) }\end{array}$} & $\begin{array}{l}\text { en. In the country of the blind, the one-eyed man is king, } \\
\text { ukr. У царстві сліпих і одноокий-король. }\end{array}$ \\
\hline & $\begin{array}{l}\text { eb. Everything else is quiet, except there was a one-armed man } \\
\text { snooping around intensive care, } \\
\text { ukr. Усе інше - спокійно, крім того, що ... якийсь однорукий } \\
\text { нишпорив навколо відділення інтенсивної терапії. }\end{array}$ \\
\hline & $\begin{array}{l}\text { en. This lovely two-toned brushed-steel model boasts a white } \\
\text { velvet interior in a French fold design, eternal rest adjustable } \\
\text { bed, and matching pillow and throw, } \\
\text { ukr. Ця відмінна двоколірна модель з матовою стали з } \\
\text { внутрішньою оббивкою з білого оксамиту, у франиузькому } \\
\text { стилі, зручне ложе для вічного сну, подушка і покривало } \\
\text { додаються. }\end{array}$ \\
\hline
\end{tabular}




\begin{tabular}{|c|c|}
\hline Model & Example \\
\hline \multirow[t]{3}{*}{$\begin{array}{l}\text { Numeral+Verb } \\
\text { (Two-timing, } \\
\text { one-step, } \\
\text { one-shot) }\end{array}$} & $\begin{array}{l}\text { en. When your lying, drug addict, two-timing ex-boyfriend } \\
\text { sends уои a beautiful wedding invitation, } \\
\text { ukr. Коли брехливий, наркозалежнй, невірний колишній } \\
\text { надсилає мені красиве запрошення на весілля. }\end{array}$ \\
\hline & $\begin{array}{l}\text { en. One-step actions led her to success, } \\
\text { ukr. Покрокові діï привели ї̈ до успіxy. }\end{array}$ \\
\hline & $\begin{array}{l}\text { en. That was a one-shot deal for them, } \\
\text { ukr. Для них ие було одноразової угодою. }\end{array}$ \\
\hline \multirow{3}{*}{$\begin{array}{l}\text { Adjective }+ \\
\text { Adjective } \\
\text { (Extra-ordinary, } \\
\text { socio-cultural, } \\
\text { dark-green) }\end{array}$} & $\begin{array}{l}\text { en. After all, most heroes are ordinary people who engage in } \\
\text { extra-ordinary moral actions, } \\
\text { ukr. Зрештою, більшість героїв є звичайними людьми, які } \\
\text { здійснюють незвичайні моральні дї. }\end{array}$ \\
\hline & $\begin{array}{l}\text { en. Language, religion and socio-cultural aspects are also } \\
\text { important differentiating factors, } \\
\text { ukr. Мова, релігія i соціально-культурні фактори також } \\
\text { мають важливе значення в прочесі накопичення традиційних } \\
\text { знань. }\end{array}$ \\
\hline & $\begin{array}{l}\text { en. You'll want your dark-green tie because it goes well with } \\
\text { your gray suit, } \\
\text { ukr. Тобi знадобиться темно-зелений галстук, він дуже } \\
\text { nідходить до твого сірого костюма. }\end{array}$ \\
\hline \multirow[t]{2}{*}{$\begin{array}{l}\text { Verb+Adverb } \\
\text { (Go-slow, } \\
\text { knock-down) }\end{array}$} & $\begin{array}{l}\text { en. Lack of political will on the part of factional leaders was } \\
\text { also apparent, as evidenced in the go-slow approach of General } \\
\text { Dostum in the поrth, } \\
\text { ukr. Настільки ж очевидною є відсутність політичноі } \\
\text { волі з боку фракиійних лідерів, про шо свідчить «поступовий» } \\
\text { підхід генерала Дустума на півночі краӥни. }\end{array}$ \\
\hline & $\begin{array}{l}\text { en. He gave it to you for a knock-down price, } \\
\text { ukr. Він віддав книгу вам за зниженою ціною. }\end{array}$ \\
\hline
\end{tabular}

According to these data we can conclude about the number of composed adjectives formed by various components, given in List 2.

List 2

\begin{tabular}{|l|c|c|}
\hline \multicolumn{1}{|c|}{ Building } & Quantity & Percentage ratio \\
\hline Adjective + Present Participle/Past Participle & 1400 & $56 \%$ \\
\hline Adjective + Noun & 350 & $14 \%$ \\
\hline Noun + Past Participle & 200 & $8 \%$ \\
\hline Adjective + Present Participle & 200 & $8 \%$ \\
\hline Adjective + Adjective & 150 & $6 \%$ \\
\hline Numeral + Past Participle & 100 & $4 \%$ \\
\hline Numeral + Verb & 50 & $2 \%$ \\
\hline Verb + Adverb & 50 & $2 \%$ \\
\hline
\end{tabular}

Quantitative analysis of composed English adjectives has confirmed that in English there is no clear scheme for the formation of composed adjectives, this may be one and the same part of the language, and different. And since each part of the language is different from the other, then in the translation of the CA, also sometimes there are differences in the semantic charge of the whole adjective. That is, in the formation of new words, the same composed adjectives have a completely different structure.

Each part of the language contains in its composition the most vivid examples, the function of which is the most complete description of the part of the language and represent 
a certain grammatical or lexical category. It is now logical to represent the largest group of composed adjectives, by quantitative analysis, formed by the Adjective + PastParticiple / PresentParticiple scheme, where the nuclear is the second component, that is, the participle which completely determines the semantics of the composed adjective.

Adjective + Adjective, Noun + Adjective - the given types of CAs do not change their structure during translation, which is noticeable through the components of a compound adjective, which is formed from a morpheme adjective and another morpheme adjective and a noun-adjective. Because of that the bases are equal, with a predicative - and therefore it is impossible to highlight the center in this type of CA.

Typological peculiarities of the English language create unlimited possibilities for word-building, which explain the value role of the composition, when by the merger of two or more bases a word new in form and content is formed (S. M. Yenikeyev).

The morphemes of adjectives or adverbs and the morphemes of past participle sentences or the present times are in greatest demand. Of course, they can be replaced by the opposition of the value of a complex adjective to the opposite or the like, that is, they are able to become an entire opposition. Therefore, we can contemplate the widespread use of synonyms or antonyms.

In modern English, a whole set of nominative units is singled out - the language field of the quantity, in which the hierarchy of the various structures with the total number of seams is presented, which reflects the systemic attitudes inherent in the surrounding world, the cognitive process, the interdependence of linguistic and social factors.

And the adjective itself as a part of the language is noted in all Indo-European languages as one of the four main parts of the language. A prospective study of quantitative CAs in the works of artistic and scientific and technical literature appears.

\section{ФУНКЦІОНАЛЬНІ ТА СЕМАНТИЧНІ ОСОБЛИВОСТІ СКЛАДЕНИХ ПРИКМЕТНИКІВ АНГЛІЙСЬКОї МОВИ (НА МАТЕРІАЛІ ХУДОЖНЬОГО АНГЛОМОВНОГО ДИСКУРСУ)}

Шуменко О. А., канд. філол. наук, доцент, https://orcid.org/0000-0002-7846-1937

E-mail: shuma-81@ukr.net,

Іншина Н., студентка,

Кашенко П, студентка,

Кострюкова В., студентка,

Сумський державний університет,

вул. Римського-Корсакова, 2, м.Суми, 40007, Украӥна

Стаття присвячена комплексному дослідженню семантичних особливостей складених прикметників на матеріалах художнього англомовного дискурсу. Актуальність даної теми зумовлена тенденцією сучасної лінгвістики до поглибленого вивчення функиіональних параметрів складених прикметників, як важливих елементів мовної картини світу. Метою статті є дослідження семантичної поведінки складених прикметників в залежності від їх складників. На основі вивчення структуризачї̈ складених прикметників виокремлено лексико-семантичні групи, на значення яких впливає сукупність значень двох складників. Для досягнення поставленої мети було проведено детальний аналіз текстів з творів англійської літератури, шо і стало джерелом інформаиї про функиіональні та семантичні властивості прикметників. Виділено основні категорії складених прикметників, Noun + Adjective, Adjective +Adjective, Numeral + Past Participle i Adjective + Past Participlel Adjective + Present Participle. Основний зміст дослідження становить аналіз останньої групи складних прикметників, яка в свою чергу поділяється на дві підгрупи Adjective + Past Participle ma Adjective + Present Participle. Даний тип характеризує прикметник найповніше, де другий компонент, дієприкметник, - ядро значення слова, шо детермінуе семантику складного прикметника. Інші типи складних прикметників дають змогу зрозуміти, що вони не змінюють своєї структури при перекладі та виявити центр значення в прикметниках даної структури неможливо, оскільки ці основи рівноправні і мають сурядний зв'язок.

Ключові слова: семантичне навантаження, ядерна основа, складені прикметники, модель утворення. 


\section{ФУНКЦІОНАЛЬНЫЕ И СЕМАНТИЧНЫЕ ОСОБЕННОСТИ СОСТАВНЫХ ПРИЛАГАТЕЛЬНЫХ АНГЛИЙСКОГО ЯЗЫКА \\ (НА МАТЕРИАЛЕ ХУДОЖЕСТВЕННОГО АНГЛОЯЗЫЧНОГО ДИСКУРСА)}

Шуменко О. А., канд. филол. наук, доцент, https://orcid.org/0000-0002-7846-1937

E-mail: shuma-81@ukr.net,

Иншина Н., студентка,

Кашенко П, студентка,

Кострюкова В., студентка

Сумский государственный университет,

ул. Римского-Корсакова, 2, м.Суми, 40007, Украина

Статья посвящена комплексному исследованию семантических особенностей составньх прилагательных на материалах художественного англоязычного дискурса. Актуальность данной темы обусловлена тенденцией современной лингвистики к углубленному изучению функииональных параметров составных прилагательных, как важных элементов языковой картины мира. Целью статьи является исследование семантического поведения составных прилагательных в зависимости от их составляющих. На основе изучения структуризации составных прилагательных выделено лексико-семантические группь, на значение которых влияет совокупность значений двух составляющих. Для достижения поставленной иели был проведен детальный анализ текстов из произведений английской литературы, что и стало источником информации о функциональных и семантических свойствах прилагательных. Выделено основные категории составных прилагательных, Noun + Adjective, Adjective +Adjective, Numeral + Past Participle i Adjective + Past Participlel Adjective + Present Participle. Основным содержанием исследования является анализ последней группы составных прилагательных, которые в свою очередь делятся на две nodzруnпь Adjective + Past Participle ma Adjective + Present Participle. Данный тип характеризует прилагательное наиболее полно, где второй компонент, причастие, - ядро значения слова, что детерминирует семантику составного прилагательного. Другие типы составных прилагательных дают возможность понять, что они не изменяют свою структуру при переводе и определить иентр значения 6 прилагательных данной структуры - невозможно, так как эти основы равноправные и имеют сочинительную связь.

Ключевые слова: семантическая нагрузка, ядерная основа, составные прилагательные, модель возникновения.

\section{СПИСОК ВИКОРИСТАНИХ ДЖЕРЕЛ}

1. Арнольд И. В. Лексикология современного английского языка. М. : Высшая школа, 1991. 140 с.

2. Гальперин И. Р. Стилистика английского языка. М. : Высшая школа, 1977. - 340 с.

3. Снікєєва С. М. Системність $і$ розвиток словотвору сучасної англійської мови : монографія. Запоріжжя : Запорізький національний ун-т, 2006. 303 с.

4. Сфімов Л. П., Ясінецька О. А. Стилістика англійської мови. Вінниця : Нова Книга, 2004. 240 с.

5. Кобозева І. М. Лінгвістична семантика. М. : Ліброком, 2009. 352 с.

6. Кочерган М. П. Слово $і$ контекст: лексична сполучуваність $i$ значення слова. Львів : Вища школа, 1980. $183 \mathrm{c}$

7. Кочерган М. П. Вступ до мовознавства : підручник. К. : Академія, 2000. 368 с

8. Лакофф Дж. Когнітивна семантика. Мова і інтелект (пер. $з$ англ. і нім.). - М. : Прогрес, 1996. -340 с.

9. Лотоцька К. Стилістика англійськой мови : навч. посібник. Львів : Видавничий центр ЛНУ ім. Івана Франка, 2008. 254 с.

10. Смирницький А. І. Значення слова. Питання мовознавства. 1995. № 2. 205 с.

11. Смирницкий А. И. Синтаксис английского языка. М. : Изд-во лит. на иностр. яз. 284 с.

12. Федоров А. В. Основы общей теории перевода (лингвистические проблемы). М. : Изд. дом «Филология», Филологический факультет СПбГУ, 2002. 416 с.

\section{СПИСОК ІЛЮСТРАТИВНОЇ ЛІТЕРАТУРИ}

13. Keeble Harry, Hollington Kris. Hurting Too Much: Shocking Stories from the Frontline of Child Protection Great Britain by CPI Group (UK) Ltd, Croydon CR0 4YY, 2012. 277 p.

14. Peterson Alice. A Song For Tomorrow. Simon \& Schuster UK; Paperback Original edition (9 Feb. 2017).

15. Thompson Kate. Secrets of the Sewing Bee. London N1 9RR by Pan Books; an imprint of Pan Macmillan 20 New Wharf Road, 10th March, 2016. 355 p.

\section{REFERENCES}

1. Arnold, I. V. (1991). Leksikologiia sovremenogo angliiskogo yazyka [Lexicology of Modern English]. Moscow, Russia: Vysshaia shkola.

2. Galperin, I. R. (1997). Stilistika angliiskogo yazyka [Stylistics of the English Language]. Moscow, Russia: Vysshaya shkola.

3. Yenikieieva, S. M. (2006). Systemnist i rozvytok slovotvoru suchasnoi anhliiskoi movy [Systems and Word Formation of Modern English]. Zaporizhzhia, Ukraine: Zaporizhzhia National University. 
4. Yefimov, L. P., \& Yasinetskaya, E. A. (2004). Stylistyka angliiskoi movy [Practical Stylistics of English]. Vinnytsia, Ukraine: Nova Knyha.

5. Kobozeva, I. M. (2009). Linhvistychna semantyka [Linguistic semantics]. Moscow: Librokom.

6. Kocherhan, M. P. (1980). Slovo i kontekst: leksychna spoluchuvanist i znachenia slova [Word and Context: Lexical Meaning and Compatibility]. Lviv, S.U.: Vyscha shkola.

7. Kocherhan, M. P. (2000). Vstup do movoznavstva: [pidruchnyk] [Introduction to Linguistics]. Kyiv: Akademiia.

8. Lakoff, Dzh. (1996). Kohnityvna semantyka [Cognitive semantics]. Mova i intelekt (per. $z$ anhl. $i$ nim.). Moscow, S.U.: Prohres.

9. Lototska, K. (2008). Stylistyka angliiskoi movy [Practical Stylistics of English]. Lviv, Ukraine: Vydavnychyi tsentr LNU im. Ivana Franka.

10. Smyrnytskyi, A. I. (1995). Znachennia slova. Pytannia movoznavstva [The meaning of the word. linguistics questions],- 205 p.

11. Smirnitsky, A. I. (1957). Sintaksis angliiskogo yazyka [Syntax of the English Language]. Moscow, S.U.

12. Fedorov, A. V. (2002). Osnovy obshei teorii perevoda (lingvisticheskie problem) [Fundamentals of the General Theory of Translation (Linguistic Problems)]. Moscow, Russia: Filologicheskii fakultet SPbGU.

\section{ILLUSTRATIONS}

13. Keeble, Harry \& Hollington, Kris. (2012). Hurting Too Much: Shocking Stories from the Frontline of Child Protection. Great Britain by CPI Group (UK) Ltd, Croydon CR0 4YY.

14. Peterson, Alice. (9 Feb. 2017). A Song For Tomorrow. Simon \& Schuster UK; Paperback Original edition

15. Thompson, Kate. (2016). Secrets of the Sewing Bee. London N1 9RR by Pan Books; an imprint of Pan Macmillan 20 New Wharf Road, 10th March.

Received: 27 May, 2018 